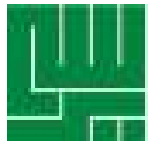

\title{
Pengaruh Tingkat Kepatuhan Minum Tablet Fe Terhadap Kejadian Anemia Pada Ibu Hamil Trimester III di Puskesmas Pejeruk Tahun 2017
}

\author{
The Influence between The Obedience Level in \\ Consuming Fe Tablet and Anemia Incidentat The Third \\ Trimester Pregnancy at Pejeruk Health Center 2017
}

\author{
Sophia Sarah, Iriantw \\ Diploma IV Program of Midwifery Health Polytechnic of Mataram
}

KATA KUNCI

KEYWORDS

ABSTRAK
Kepatuhan Minum Tablet Fe; Anemia; Ibu Hamil

Obedience in Consuming Fe Tablet; Anemia; Pregnant

Woman

Berdasarkan hasil Riskesdas tahun 2013, prevalensi anemia pada ibu hamil di Indonesia sebesar 37,1\%. Pada tahun 2015, di Kota Mataram tercacat sekitar 8,11\% kasus dan di Puskesmas Pejeruk merupakan kasus tertinggi yaitu sedangkan cakupan pemberian tablet Fe-3 sebesar 92,26\%. Cakupan pemberian tablet Fe yang tinggi bisa tidak berdampak pada penurunan anemia besi jika kepatuhan ibu hamil dalam mengkonsumsi tablet Fe masih rendah.

Untuk mengetahui pengaruh tingkat kepatuhan minum tablet Fe terhadap kejadian anemia pada ibu hamil trimester III di Puskesmas Pejeruk.

Penelitian ini dilaksanakan dengan desain jenis penelitian observasional analitik menggunakan cross sectional dengan jumlah sampel sebanyak 30 orang. Data yang dikumpulkan berupa data karakteristik responden, data kepatuhan yang diukur menggunakan kuisioner MMAS-8 dan data hasil pemeriksaan kadar hemoglobin.

Ibu yang mengalami anemia dan memiliki tingkat kepatuhan rendah dalam mengkonsumsi tablet $\mathrm{Fe}(43,3 \%)$ lebih banyak dibandingkan yang yang memiliki tingkat kaptuhan tinggi dalam mengkonsumsi tablet Fe (6,7\%). Hasil uji statistik menggunakan Chi Square diperoleh $p=0,001$. Ada pengaruh tingkat kepatuhan ibu hamil trimester III dalam mengkonsumsi tablet Fe terhadap kejadian anemia di Puskesmas Pejeruk 2017. 
ABSTRACT Based on the results of Riskesdas in 2013, the prevalence of anemia of pregnant women in Indonesia is 37.1\%. In 2015, Mataram is recordedfor about $8.11 \%$ of incidence and Pejeruk Health Center get highest anemia cases of pregnant women, the giving of Fe-3 tablets is about $92.26 \%$. The high coverage of the Fe tablets giving cannot be affected of the decreasing anemia cases if the obedience level of pregnant woman in taking the Fe tablets still low.

To investigate the influence of obedience level in taking the Fe tablets towards the anemia cases in third trimester pregnant women at Pejeruk Community Health Center.

This research was conducted by applying observational analytic research and the use cross sectional with 30 samples. Data collection is in the form of respondent data characteristics, the obedience data was measured by using MMAS-8 and data of hemoglobin level.

The result shows that the mothers with anemia and have low of obedience in consuming Fe tablets (43,3\%) is more than those who had high levels of obedience in taking the Fe tablets $(6,7 \%)$. The result of statistical test by using Chi Square obtained $p=0,001$.

There is influence between obedience level of third trimester pregnant woman in consuming Fe tablet andanemia cases at Pejeruk Health Center 2017.

\section{PENDAHULUAN}

Derajat kesehatan masyarakat dapat dilihat antara lain dari angka kematian, angka kesakitan dan status gizi. Survei Demografi Kesehatan Indonesia tahun 2012 menunjukkan peningkatan AKI yang signifikan yaitu menjadi 359 kematian ibu per 100.000 kelahiran hidup (Badan Pusat Statistik RI 2012). Tiga faktor utama penyebab kematian ibu melahirkan yakni, pendarahan, hipertensi saat hamil atau pre eklamasi dan infeksi. Pendarahan menempati persentase tertinggi penyebab kematian ibu (28\%), anemia dan kekurangan energi kronis (KEK) pada ibu hamil menjadi penyebab utama terjadinya pendarahan dan infeksi yang merupakan faktor kematian utama ibu.
Berdasarkan hasil Riset Kesehatan Dasar (Riskesdas) tahun 2013, prevalensi anemia pada ibu hamil di Indonesia sebesar 37,1\%. Pada tahun 2015, di Kota Mataram sekitar 8,11\% ibu hamil mengalami anemia dan Puskesmas Pejeruk Provinsi Nusa Tenggara Barat merupakan puskesmas dengan kasus anemia pada ibu hamil tertinggi yaitu sebesar 26,53\% (DinKes Mataram 2015). Kemudian pada tahun 2016 menjadi 35,20\% (Puskesmas Pejeruk 2016). Menunjukkan trend kejadian anemia terus mengalami peningkatan, sehingga masih menjadi masalah pada ibu hamil.

\footnotetext{
Correspondence:

Sophia Sarah, Diploma IV Midwifery Health

Polytechnic Mataram

Email:sophiasarrah@gmail.com
} 
Kita bisa mendeteksi adanya masalah kesehatan selama kehamilan dengan pemeriksaan antenatal sehingga kita bisa melakukan pencegahan terhadap anemia defisiensi besi selama masa kehamilan melalui pemberian suplementasi besi yang sangat vital bagi pertumbuhan dan fungsi awal otak fetal. Pemberian tabelt Fe pada ibu hamil juga merupakan salah satu prosedur tetap pelayanan ibu hamil yang diberikan bidan dalam kunjungan 1 sampai 4. Adapun jumlah suplemen zat besi yang diberikan selama kehamilan ialah sebanyak 90 tabelt (Fe3). Pencatatan yang dilakukan adalah ibu hamil menerima tabelt zat besinya, terlepas dari apakah tabelt tersebut diminum atau tidak. Pada Tahun 2016 cakupan pemberian tabelt Fe-1 di Puskesmas Pejeruk sebesar 107, 93\% dan cakupan tabelt Fe-3 sebesar 92,26\% (Puskesmas Pejeruk 2016).

Efektivitas upaya pemberian tabelt $\mathrm{Fe}$ juga bergantung pada kepatuhan ibu hamil dalam mengkonsumsi tabelt besi yang diberikan. Cakupan pem-berian tabelt Fe yang tinggi bisa tidak berdampak pada penurunan anemia besi jika kepatuhan ibu hamil dalam mengkonsumsi tabelt Fe masih rendah (Dinas Kesehatan Provinsi NTB 2015). Berdasarkan permasalahan diatas, maka penelitian ini bertyujuan untuk mengetahui pengaruh tingkat kepatuhan minum tabelt Fe terhadap kejadian anemia pada ibu hamil trimester III di Puskesmas Pejeruk Tahun 2017.

\section{CARA KERJA}

Penelitian ini menggunakan jenis rancangan penelitian Observasional Analitik dengan Cross Sectional yang bertujuan untuk mengetahui apakah ada pengaruh tingkat kepatuhan minum tabelt Fe terhadap kejadian anemia pada ibu hamil trimester III di Puskesmas Pejeruk Tahun 2017. Penelitian ini dilakukan pada tanggal 8 s/d 29 Mei 2017 di Puskesmas Pejeruk Provinsi Nusa Tenggara Barat pada ibuibu hamil trimester III yang memenuhi kriteria inklusi. Besar sampel yang digunakan adalah sampel minimal sebanyak 30 responden. Peneliti menggunakan tingkat kemaknaan $\mathrm{p}=0,05$ dan confidence interval ( $95 \%$ ).

Variabel terikat dalam penelitian ini adalah kejadian anemia pada ibu hamil trimester III. Selain itu dikumpulkan pula variabel tentang karakteristik ibu (umur, pendidikan, pekerjaan, paritas, dan jarak kehamilan). Informasi tentang kejadian anemia dan variabel-variabel di atas dikumpulkan melalui membaca hasil pemeriksaan hemoglobin yang dilakukan pada saat penelitian dan wawancara terhadap responden. Analisis univariat bertujuan untuk mendeskripsikan karakteristik masingmasing variabel yang diteliti. Sedangkan, analisis bivariat bertujuan untuk menguji perbedaan dan menguji pengaruh variabel bebas terhadap variabel terikat. 


\section{HASIL}

Berdasarkan hasil penelitian, umur responden sebagian besar berkisar pada 20-35 tahun yaitu sebanyak 26 orang $(86,7 \%)$. Hal tersebut dapat dilihat pada tabel di bawah ini.

Tabel 1. Distribusi Jumlah Responden

Berdasarkan Kelompok Umur di

Puskesmas Pejeruk Tahun 2017

\begin{tabular}{lrr}
\hline \multicolumn{1}{c}{ Umur } & Jumlah & $\%$ \\
\hline $20-35$ & 26 & 86,7 \\
$>35$ tahun & 4 & 13,3 \\
\hline Total & 30 & 100,0 \\
\hline
\end{tabular}

Terkait dengan tingkat pendidikan diketahui bahwa tingkat pendidikan responden yang tertinggi yaitu tamat SLTA sebanyak 11 orang $(36,7 \%)$ dan tingkat pendidikan responden yang terendah yaitu tamat SLTP sebanyak 4 orang $(13,3 \%)$. Hal tersebut dapat dilihat pada tabel di bawah ini.

Tabel 2. Distribusi Jumlah Responden

Berdasarkan Tingkat Pendidikan di

Puskesmas Pejeruk Tahun 2017

\begin{tabular}{lrr}
\hline \multicolumn{1}{c}{ Pendidikan } & Jumlah & $\%$ \\
\hline Tamat SD & 8 & 26,7 \\
Tamat SLTP & 4 & 13,3 \\
Tamat SLTA & 11 & 36,7 \\
Akademi/Universitas & 7 & 23,3 \\
\hline Total & 30 & 100,0 \\
\hline
\end{tabular}

Sedangkan pekerjaan responden yang tertinggi yaitu ibu rumah tangga sebanyak 17 orang $(56,7 \%)$ dan pekerjaan responden yang terendah yaitu wiraswasta sebanyak 1 orang $(3,3 \%)$. Hal tersebut dapat dilihat pada tabel di bawah ini.
Tabel 3. Distribusi Jumlah Responden Berdasarkan Jenis Pekerjaan di Puskesmas Pejeruk Tahun 2017

\begin{tabular}{lrr}
\hline \multicolumn{1}{c}{ Pekerjaan } & Jumlah & \multicolumn{1}{c}{$\%$} \\
\hline Ibu rumah tangga & 17 & 56,7 \\
Wiraswasta & 1 & 3,3 \\
Pegawai swasta & 6 & 20,0 \\
Lain-lain & 6 & 20,0 \\
\hline Total & 30 & 100,0 \\
\hline
\end{tabular}

Jika ditinjau berdasarkan jumlah paritas, sebagian besar responden meruapakan multigravida yaitu sebanyak 22 orang (73,3\%). Hal tersebut dapat dilihat pada tabel di bawah ini.

Tabel 4. Distribusi Jumlah Responden

Berdasarkan Jumlah Paritas di

Puskesmas Pejeruk Tahun 2017

\begin{tabular}{lcr}
\hline \multicolumn{1}{c}{ Paritas } & Jumlah & $\%$ \\
\hline Primigravida & 8 & 26,7 \\
Multigravida & 22 & 73,3 \\
\hline Total & 30 & 100,0 \\
\hline
\end{tabular}

Sedangkan jarak kehamilan responden yang tertinggi yaitu berkisar pada 2-5 tahun sebanyak 10 orang $(45,5 \%)$ dan jarak kehamilan responden yang terendah yaitu $<2$ tahun sebanyak 3 orang $(13,6 \%)$. Hal tersebut dapat dilihat pada tabel di bawah ini.

Tabel 5. Distribusi Jumlah Responden Berdasarkan Jarak Kehamilan di Puskesmas Pejeruk Tahun 2017

\begin{tabular}{lrr}
\hline \multicolumn{1}{c}{ Jarak } & Jumlah & \multicolumn{1}{c}{$\%$} \\
\hline Kehamilan & & \\
2 2 Tahun 5 tahun & 3 & 13,6 \\
$>$ 5 Tahun & 10 & 45,5 \\
\hline Total & 9 & 40,9 \\
\hline
\end{tabular}


Berdasarkan hasil penelitian terlihat bahwa tingkat kepatuhan responden yang tertinggi yaitu tingkat kepatuhan rendah sebanyak 15 orang atau $50,0 \%$ dan tingkat kepatuhan yang terendah yaitu tingkat kepatuhan sedang sebanyak 7 orang atau 23,3\%. Hal tersebut dapat dilihat pada tabel di bawah ini.

Tabel 6. Distribusi Jumlah Responden Berdasarkan Tingkat Kepatuhan di Puskesmas Pejeruk Tahun 2017

\begin{tabular}{lrr}
\hline $\begin{array}{c}\text { Tingkat } \\
\text { Kepatuhan }\end{array}$ & Jumlah & $\%$ \\
\hline Kepatuhan tinggi & 8 & 26,7 \\
Kepatuhan sedang & 7 & 23,3 \\
Kepatuhan rendah & 15 & 50,0 \\
\hline Total & 30 & 100,0 \\
\hline
\end{tabular}

Berdasarkan hasil penelitian juga terlihat bahwa alasan responden tidak patuh dalam mengkonsumsi tabelt Fe yang tertinggi yaitu karena lupa sebanyak 9 orang atau 40,9\% dan alasan yang terendah yaitu karena mengalami efek samping sebanyak 2 orang atau 9,1\%. Hal tersebut dapat dilihat pada tabel di bawah ini.

Tabel 7. Distribusi Jumlah Responden Berdasarkan Alasan Ibu Hamil Tidak Patuh Dalam Meng-konsumsi Tabelt Fe di Puskesmas Pejeruk Tahun 2017

\begin{tabular}{lcr}
\hline \multicolumn{1}{c}{ Alasan } & Jumlah & $\%$ \\
\hline Lupa meng-konsumsi & 9 & 40,9 \\
Mengalami efek & 2 & 9,1 \\
samping & 5 & 22,8 \\
Tidak kontrol & 3 & 13,6 \\
Merasa sehat & 3 & 13,6 \\
Merasa tidak nyaman & 22 & 100,0 \\
\hline \multicolumn{1}{c}{ Total } & &
\end{tabular}

Sedangkan, jika ditinjau berdasarkan jumlah penderita anemia maka terlihat bahwa sebagian besar responden mengalami anemia yaitu sebanyak 22 orang atau 73,3\%. Hal tersebut dapat dilihat pada tabel di bawah ini.

Tabel 8. Distribusi Jumlah Responden Berdasarkan Kejadian Anemia di Puskesmas Pejeruk Tahun 2017

\begin{tabular}{crr}
\hline Kejadian Anemia & Jumlah & \multicolumn{1}{c}{$\%$} \\
\hline Anemia & 22 & 73,3 \\
Tidak anemia & 8 & 26,7 \\
\hline Total & 30 & 100,0 \\
\hline
\end{tabular}

Oleh karena itu diperoleh hasil bahwa responden yang mengalami anemia dari 22 orang atau 73,3\% lebih banyak berasal dari responden dengan tingkat kepatuhan rendah yaitu sebanyak 13 orang $(43,3 \%)$ dan kepatuhan sedang sebanyak 7 orang $(23,3 \%)$. Sedangkan responden yang tidak mengalami anemia dari 8 orang atau $26,7 \%$ lebih banyak berasal dari responden dengan tingkat kepatuhan tinggi yaitu sebanyak 6 orang $(20,0 \%)$. Hal tersebut dapat terlihat pada tabel di bawah ini.

Tabel 9. Distribusi Kejadian Anemia Berdasarkan Tingkat Kepatuhan Ibu Hamil Trimester III Dalam Mengkonsumsi Tabelt Fe di Puskesmas Pejeruk Tahun 2017

\begin{tabular}{|c|c|c|c|c|c|c|}
\hline \multirow{2}{*}{ Variabel } & \multicolumn{4}{|c|}{$\begin{array}{l}\text { Kejadian } \\
\text { Anemia }\end{array}$} & \multirow{2}{*}{ Total } & \multirow{3}{*}{ P Value } \\
\hline & \multicolumn{4}{|c|}{ Anemia $\begin{array}{c}\text { Tidak } \\
\text { anemia }\end{array}$} & & \\
\hline $\begin{array}{l}\text { Tingkat } \\
\text { Kepatuhan }\end{array}$ & $\mathrm{n}$ & $\%$ & $\mathrm{n}$ & $\%$ & $\mathrm{n} \quad \%$ & \\
\hline $\begin{array}{l}\text { Kepatuhan } \\
\text { tinggi }\end{array}$ & 2 & 6,7 & 6 & 20,0 & $\begin{array}{ll}8 & 26,7\end{array}$ & \\
\hline $\begin{array}{l}\text { Kepatuhan } \\
\text { sedang }\end{array}$ & 7 & 23,3 & 0 & 0,0 & 723,3 & 0,001 \\
\hline $\begin{array}{l}\text { Kepatuhan } \\
\text { rendah }\end{array}$ & 13 & 43,3 & 2 & 6,7 & 15 50,0 & \\
\hline Total & 22 & 73,3 & 8 & 26,7 & 30100,0 & \\
\hline
\end{tabular}


Dari hasil uji statistik dengan menggunakan uji chi square pada diperoleh nilai $\mathrm{p}=0,001$ atau $\mathrm{p}<0,05$. Karena terdapat sel yang mempunyai nilai expected kurang dari 5 lebih dari $20 \%$ dari jumlah sel, maka dilakukan uji Yates Correction. Dari hasil perhitungan yates correction diperoleh nilai 9,4 sedangkan chi square tabel adalah 5,991 maka nilai koreksi yates lebih besar dari nilai chi square tabel. Dengan demikian Ho ditolak dan Ha diterima, artinya terdapat perbedaan yang signifikan sehingga ada pengaruh tingkat kepatuhan minum tabelt Fe terhadap kejadian anemia pada ibu hamil trimester III di Puskesmas Pejeruk.

Disamping hal-hal yang tealh disampaikan, berdasarkan hasil penelitian ini terlihat bahwa varibael pendidikan, pekerjaan, paritas, dan jarak kehamilan merupakan variabel pengganggu (confounding) dalam penelitian ini dengan nilai $\mathrm{p}<0,05$. Sedangkan variabel umur bukan merupakan variabel pengganggu dalam penelitian ini karena diperoleh nilai $p>0,05$. Hal tersebut dapat dilihat pada tabel di bawah ini.

Tabel 10. Distribusi Faktor PengGanggu Yang Mem-Pengaruhi Tingkat Kepatuhan Minum Tabelt Fe Terhadap

Kejadian Anemia Pada Ibu Hamil Trimester III di Puskesmas Pejeruk Tahun 2017

\begin{tabular}{lcc}
\hline \multirow{2}{*}{$\begin{array}{c}\text { Faktor } \\
\text { pengganggu }\end{array}$} & \multicolumn{2}{c}{$\begin{array}{c}\text { Mantel-Haenszel Common } \\
\text { Odds Ratio Estimate }\end{array}$} \\
\cline { 2 - 3 } & Estimate & P Value \\
\hline Umur & 10,000 & 0,064 \\
Pendidikan & 23,667 & 0,003 \\
Pekerjaan & 26,353 & 0,004 \\
Paritas & 43,250 & 0,004 \\
Jarak & 37,800 & 0,012 \\
Kehamilan & & \\
\hline
\end{tabular}

\section{PEMBAHASAN}

Semakin cukup umur, tingkat kematangan dan kekuatan seseorang akan lebih matang dalam berpikir dan mengambil suatu keputusan serta mempengaruhi kepatuhan (Kamidah 2013). Berdasarkan Tabel 1 terlihat bahwa responden dengan umur terbanyak yaitu $20 \mathrm{~s} / \mathrm{d} 35$ tahun sebanyak 26 orang $(86,7 \%)$. Semakin tua umur seseorang maka proses perkembangan mental-nya bertambah baik, akan tetapi pada umur tertentu, bertambahnya proses perkembangan mental ini tidak secepat ketika berusia belasan tahun, dengan demikian dapat disimpulkan faktor umur akan mempengaruhi tingkat pengetahuan seseorang yang akan mengalami puncaknya pada umur tertentu dan akan menurun kemampuan penerimaan atau mengingat sesuatu seiring dengan usia semakin lanjut. Semakin muda seseorang semakin mudah pula menyerap apa yang disampaikan. Pendidikan dapat dianggap sebagai pengalaman yang berfungsi untuk mengembangkan kemampuan dan kualitas pribadi seseorang, dimana semakin tinggi tingkat pendidikan akan semakin besar kemampuannya untuk memanfaatkan pengetahuan dan keterampilannya (Syamsiah N 2011).

Tingkat pendidikan seseorang akan berpengaruh dalam memberi respon terhadap sesuatu sehingga perbedaan tingkat pendidikan mengakibatkan perbedaan pengetahuan yang diperoleh responden tentang konsumsi tabelt Fe (Sulistiyanti A 2015). Berdasarkan Tabel 2 terlihat bahwa responden yang memiliki tingkat pendidikan terbanyak yaitu tamat SLTA sebanyak 11 orang (36,7\%). Latar belakang pendidikan ibu hamil juga sangat berpengaruh terhadap 
kepatuhan ibu meminum tabelt Fe. Seharusnya bisa dilihat dari tingkat pendidikannya mereka mengerti dan lebih memiliki wawasan tentang kebutuhan selama kehamilan terutama kebutuhan akan pentingnya tabelt Fe selama kehamilan untuk mencegah terjadinya kekurangan darah. Tetapi pada kenyataannya jika dilihat berdasarkan hasil penelitian ini, beberapa dari mereka yang memiliki pendidikan sekolah lanjut tingkat atas yang memiliki tingkat kesadaran yang cukup rendah.

Berdasarkan Tabel 3 terlihat bahwa responden yang memiliki pekerjaan terbanyak yaitu ibu rumah tangga sebanyak 17 orang (56,7\%). Pekerjaan sebagai ibu rumah tangga terdapat keterbatasan dalam mempunyai sosialisasi dan interaksi dibandingkan dengan ibu yang bekerja. Proses sosialisasi dan interaksi dapat mempengaruhi pengetahuan ibu tentang konsumsi tabelt Fe (Sulistiyanti A 2015).

Salah satu faktor struktur sosial seperti pekerjaan akanmempengaruhi pemanfaatan pelayanan kesehatan, pekerjaan seseorangdapat mencerminkan sedikit banyaknya informasi yang diterima, informasitersebut akan membantu seseorang dalam mengambil keputusan untuk memanfaatkan pelayanan kesehatan yang ada (Lestari DD 2015). Berdasarkan Tabel 4 terlihat bahwa responden dengan jumlah paritas terbanyak yaitu multigravida sebanyak 22 orang (73,3\%). Dalam hal paritas, semakin banyakjumlah gravida, semakin ibu hamil tidak patuh mengkonsumsi tabelt Fe. Ibu hamil dengan kehamilan kedua, ketiga, dan seterusnya merasakehamilan tersebut sebagai hal yang normal, biasa dan sudah pernahmelahirkan, sehingga konsep tersebut mengakibatkan menurunnya perhatian terhadap pemeliharaan kehamilannya. Keadaan tersebut membahayakan bagi kesehatan ibuhamil, karena semakin tua umur ibu maka kondisi kesehatan semakin menurun (Lestari DD 2015). Berdasarkan Tabel 5 terlihat bahwa responden yang memiliki jarak kehamilan terbanyak yaitu 2-5 tahun sebanyak 10 orang $(45,5 \%)$. Seorang wanita yang hamil dan melahirkan kembali dengan jarak yang pendek dari kehamilan sebelumnya, akan memberikan dampak yang buruk terhadap kondisi kesehatan ibu dan bayi. Hal ini disebabkan, karena bentuk dan fungsi organ reproduksi belum kembali dengan sempurna. Sehingga fungsinya akan terganggu apabila terjadi kehamilan dan persalinan kembali. Jarak kehamilan minimal agar organ reproduksi dapat berfungsi kembali dengan baik adalah 24 bulan (Kusumawati Y 2006).

Seorang ibu hamil dapat dikatakan patuh dalam mengkonsumsi tabelt Fe apabila ibu hamil tersebut mengkonsumsi tabelt Fe setiap hari dan jumlah tabelt Fe yang diminum paling sedikit 90 tabelt berturut-turut selama kehamilan (Lestari DD 2015). Salah satu cara yang sederhana untuk mengukur kepatuhan adalah dengan menggunakan kuesioner. Kuesioner MMAS digunakan untuk menilai kepatuhan mengkonsumsi obat dengan rentang nilai 0 sampai 8 . Kategori respon terdiri dari ya dan tidak. Item nomor 1 sampai 4 dan 6 sampai 7 nilai 1 untuk jawaban tidak. Item 5 nilai 1 untuk jawaban ya dan 5 skala likert untuk 1 item pertanyaan nomor 8 dengan nilai 1 untuk jawaban tidak pernah 0 untuk jawaban pernah (Mursiany dkk. 2013). MMAS 
dikategorikan menjadi 3 tingkat kepatuhan obat: kepatuhan tinggi (nilai 8), kepatuhan sedang $(6-<8)$ dan kepatuhan rendah (nilai <6) (Plakas $S$ et al., 2016). Berdasarkan Tabel 6 terlihat bahwa responden yang memiliki tingkat kepatuhan terbanyak yaitu kepatuhan rendah sebanyak 15 orang (50\%). Adapun responden yang memiliki tingkat kepatuhan rendah jumlahnya banyak, hal ini disebabkan oleh beberapa alasan antara lain lupa, efek samping yaitu berupa mual, dan tidak kontrol kembali ke puskesmas/pusat pelayanan kesehatan.

Berdasarkan Tabel 7 terlihat bahwa 9 responden atau 40,9\% mengatakan alasan tidak patuh dalam mengkonsumsi tabelt Fe karena lupa. Hasil penelitian tersebut sejalan dengan penelitian yang dilakukan oleh Dawe dkk pada tahun 2008 di wilayah Bicol, Filipina yang menemukan beberapa alasan ibu hamil tidak mengkonsumsi tabelt besi yaitu 78,8\% lupa, 20,2\% mengalami efek samping, 10,3\% merasa tidak nyaman dan sebesar $9,9 \%$ menyatakan ketidaktersediaan obat (Kertiasih et al., 2013). Seorang ibu hamil dapat dikatakan mengalami anemia dalam kehamilan apabila kadar $\mathrm{Hb}<11,00 \mathrm{gr} \%$ pada trimester I dan III atau kadar $\mathrm{Hb}<10,50 \mathrm{gr} \%$ pada trimester II (Sarwono P 2014). Berdasarkan Tabel 8 terlihat bahwa responden masih ditemukan sejumlah 22 responden atau $73,3 \%$ yang mengalami anemia dan sejumlah 8 responden atau 26,7\% yang tidak mengalami anemia. Masih adanya kasus anemia pada ibu hamil dapat disebabkan karena ibu hamil memiliki tingkat kepatuhan yang rendah dalam mengkonsumsi tabelt $\mathrm{Fe}$ selama kehamilan. Konsumsi tabelt Fe yang tidak teratur dapat menyebabkan ibu hamil kekurangan zat besi yang berhubungan dengan anemia pada ibu hamil. Anemia kehamilan dapat disebabkan oleh beberapa hal salah satunya adalah kurangnya konsumsi zat besi selama masa kehamilan. Kurang zat besi dapat disebabkan oleh kurang masuknya unsur besi dalam makanan, gangguan resorpsi atau karena terlampau banyaknya zat besi yang keluar dari dalam tubuh kekurangan zat besi akan menghambat pembentukan hemoglobin yang berakibat pada terhambatnya pembentukan sel darah merah (Sarwono P 2014).

Berdasarkan Tabel 9 di atas dapat diketahui bahwa responden yang mengalami anemia dan memiliki tingkat kepatuhan rendah dalam mengkonsumsi tabelt Fe (43,3\%) lebih banyak dibandingkan responden yang memiliki tingkat kepatuhan tinggi dalam mengkonsumsi tabelt Fe (6,7\%). Sedangkan responden yang tidak mengalami anemia dan memiliki tingkat kepatuhan tinggi mengkonsumsi tabelt Fe $(20,0 \%)$ lebih banyak dibandingkan responden yang memiliki tingkat kepatuhan rendah $(6,7 \%)$. Hasil uji statistik dengan menggunakan uji Chi Square diperoleh ada pengaruh tingkat kepatuhan minum tabelt Fe terhadap kejadian anemia pada ibu hamil trimester III di Puskesmas Pejeruk dengan nilai $p=0,001$. Dikarenakan terdapat sel yang mempunyai nilai expected kurang dari 5 sebanyak 50\% dari jumlah sel, maka dilakukan uji Yates Correction. Dari hasil perhitungan yates correction diperoleh nilai 9,4 sedangkan chi square tabel adalah 5,991 maka nilai koreksi yates lebih besar dari nilai chi square tabel. Dengan demikian Ho ditolak dan $\mathrm{Ha}$ diterima, artinya semakin tinggi tingkat kepatuhan minum tabelt Fe maka 
semakin rendah resiko kejadian anemia pada ibu hamil trimester III.

Hasil penelitian ini sejalan dengan penelitian Putri S (2015) yang menyatakan terdapat hubungan cara konsumsi tabelt fe dengan kejadian anemia pada ibu hamil trimester II dan III $\quad(p=0,000)$. Tingkat anemia dipengaruhi oleh kepatuhan mengkonsumsi tabelt Fe yang diukur dari ketepatan jumlah tabelt Fe yang dikonsumsi, frekuensi tabelt Fe yang dikonsumsi dan cara konsumsi tabelt Fe. Selain itu, Hidayah, W dan Anasari, $\mathrm{T}$ (2012) melakukan penelitian yang menyatakan ada hubungan antara kepatuhan ibu hamil mengkonsumsi tabelt Fe dengan kejadian anemia di Desa Pageraji Kecamatan Cilongok Kabupaten Banyumas dengan nilai $\mathrm{p}=0,005$. Penelitian Salman $Y$, dkk (2015) menyatakan bahwa hasil analisa statistik dengan uji chi squer didapatkan nilai $\rho=0.003$ berada di bawah $\alpha=0,05$, sehingga dapat disimpulkan bahwa ada hubungan yang bermakna antara pola konsumsi zat besi dengan kejadian anemia di wilayah kerja Puskesmas Sambung Makmur tahun 2015. Zat besi merupakan mikroelemen yang esensial bagi tubuh. Zat ini terutama diperlukan dalam hemopoboesis (pembentukan darah) yaitu sintesis hemoglobin $(\mathrm{Hb})$. Hemoglobin $(\mathrm{Hb})$ yaitu suatu oksigen yang mengantarkan eritrosit berfungsi penting bagi tubuh. Hemoglobin terdiri dari $\mathrm{Fe}$ (zat besi), protoporfirin, dan globin $(1 / 3$ berat $\mathrm{Hb}$ terdiri dari $\mathrm{Fe}$ ) (Susiloningtyas I 2012).

Kebutuhan zat besi selama hamil yaitu rata-rata $800 \mathrm{mg}-1040 \mathrm{mg}$. Kebutuhan ini diperlukan $\pm 300 \mathrm{mg}$ untuk pertumbuhan janin, $\pm 50-75 \mathrm{mg}$ untuk pembentukan plasenta, $\pm 500 \mathrm{mg}$ digunakan untuk meningkatkan massa haemoglobin maternal/sel darah merah, $\pm 200 \mathrm{mg}$ lebih akan dieksresikan lewat usus, urin dan kulit, dan $\pm 200 \mathrm{mg}$ lenyap ketika melahirkan (Susiloningtyas I 2012). Kepatuhan minum tabelt Fe adalah ibu hamil yang mengkonsumsi tabelt Fe setiap hari dan jumlah tabelt Fe yang diminum paling sedikit 90 tabelt berturut-turut selama kehamilan (Lestari DD 2015). Perhitungan makan 3x sehari atau 10002500 kalori akan menghasilkan sekitar 10-15 mg zat besi perhari, namun hanya $1-2 \mathrm{mg}$ yang di absorpsi. Jika ibu mengkonsumsi $60 \mathrm{mg}$ zat besi, maka diharapkan 6-8mg zat besi dapat diabsropsi, jika dikonsumsi selama 90 hari maka total zat besi yang diabsropsi adalah sebesar $720 \mathrm{mg}$ dan $180 \mathrm{mg}$ dari konsumsi harian ibu (Susiloningtyas I 2012). Besi dalam bentuk fero lebih mudah diabsorbsi maka preparat besi untuk pemberian oral tersedia dalam berbagai bentuk berbagai garam fero seperti fero sulfat, fero glukonat, dan fero fumarat. Di Indonesia, pil besi yang umum digunakan dalam suplementasi zat besi adalah ferrosus sulfat, senyawa ini tergolong murah dan dapat diabsorbsi sampai 20\%. Pemberian preparat $60 \mathrm{mg} /$ hari dapat menaikan kadar $\mathrm{Hb}$ sebanyak 1gr\%/bulan. Saat ini program nasional menganjurkan kombinasi $60 \mathrm{mg}$ besi dan 50nanogram asam folat untuk profilaksis anemia (Susiloningtyas I 2012). Dengan demikian, semakin tinggi tingkat kepatuhan ibu hamil dalam mengkonsumsi tabelt $\mathrm{Fe}$ makan semakin rendah risiko ibu hamil mengalami anemia defisiensi zat besi begitupun sebaliknya. Berdasarkan Tabel 10 terlihat bahwa variabel pendidikan, pekerjaan, paritas, dan jarak kehamilan merupakan variabel pengganggu (confounding) dalam penelitian ini dengan nilai $\mathrm{p}<0,05$. 
Sedangkan variabel umur bukan merupakan variabel pengganggu dalam penelitian ini karena diperoleh nilai $p>0,05$.

\section{SIMPULAN}

Setelah dilakukan penelitian, dari 30 responden menunjukkan bahwa responden yang memiliki tingkat kepatuhan rendah sebanyak $50 \%$ dan dari 30 responden terdapat $73,3 \%$ responden mengalami anemia kehamilan pada trimester III. Hasil uji statistik diperoleh hasil yang signifikan bahwa ada pengaruh tingkat kepatuhan ibu hamil trimester III dalam mengkonsumsi tabelt Fe terhadap kejadian anemia $(p=0,001)$. Hasil uji mantel haenszel menunjukkan bahwa variabel pendidikan, pekerjaan, paritas dan jarak kehamilan merupakan variabel pengganggu $(p<0,05)$.

\section{Ucapan Terima Kasih}

Ucapan terima kasih disampaikan kepada ibu-ibu yang telah menjadi responden penelitian ini serta semua pihak yang telah membantu sehingga penelitian ini bisa terlaksana sesuai dengan yang direncanakan.

\section{KEPUSTAKAAN}

Badan Pusat Statistik RI 2012. Survei Demografi Kesehatan Indonesia (SDKI). Jakarta: Badan Pusat Statistik RI.

Dinas Kesehatan Kota Mataram 2015. Laporan Pemantauan Wilayah Setempat Kesehatan Ibu dan Anak Kota Mataram 2015. Mataram: Dikes Kota Mataram.

Dinas Kesehatan Provinsi NTB 2015. Profil Kesehatan Provinsi NTB 2014. NTB: Dikes Provinsi NTB.
Hidayah, W dan Anasari T 2010. Hubungan Kepatuhan Ibu Hamil Mengkonsumsi Tabelt Fe dengan Kejadian Anemia di Desa Pageraji Kecamatan Cilongok Kabupaten Banyumas.Jurnal Ilmu Kebidanan Vol. 3 No. 2 Edisi Desember 2012 (hlm. 41-53).

Kamidah 2013. Faktor-faktor yang Mempengaruhi Kepatuhan Ibu Hamil Mengkonsumsi Tabelt Fe di Puskesmas Simo Boyolali.Jurnal KesehatanSekolah Tinggi Ilmu Kesehatan 'Aisyiyah Surakarta Gaster Vol. XII No. 1 Februari 2015 (hlm. 36-45).

Kementrian Kesehatan RI 2013. Riset Kesehatan Dasar 2013. Jakarta: Badan Penelitian dan Pengembangan Kesehatan Kemenkes RI.

Kertiasih NW dan Ani LS 2013. Kepatuhan Minum Tabelt Besi pada Ibu Hamil di Wilayah Kerja Puskesmas Mengwi I Kabupaten Badung.Skripsi Fakultas Kedokteran Univeristas Udayana, Denpasar.

Kusumawati Y 2006. Faktor-Faktor resiko yang Berpengaruh terhadap Persalinan dengan Tindakan. Tesis Program Studi Epidemiologi Universitas Diponegoro, Semarang.

Lestari DD 2015. Pengaruh Pendidikan Kesehatan dan SMS Reminder terhadap Kepatuhan Ibu Hamil dalam Mengkonsumsi Tabelt Besi di Wilayah Kerja Puskesmas Pisangan Tahun 2015.Skripsi Fakultas Kedokteran dan Ilmu Kesehatan Universitas Islam Negeri Syarif Hidayatullah, Jakarta.

Mursiany dkk. 2013. Gambaran Penggunaan Obat dan Kepatuhan Mengkonsumsi Obat pada Penyakit Hipertensi di Instalasi Rawat Jalan RSUD Kraton Kabupaten Pekalongan Tahun 2013.Skripsi Program Studi Farmasi Universitas Pekalongan, Pekalongan.

Plakas S et al., 2016. Validation of the 8-item Morisky Medication Adherence Scale in Chronically III Ambulatory Patients in Rural Greece. Open Jurnal of Nursing, 2016, 6, 158-169, Scientific Research Publishing. 
Puskesmas Pejeruk 2016. Profil Kesehatan Puskesmas Pejeruk 2016. Matarm: Puskesmas Pejeruk.

Putri S 2015. Hubungan Cara Mengkonsumsi Tabelt $\mathrm{Fe}$ dengan kejadian Anemia pada Ibu Hamil Trimester II dan III di Puskesmas Tegal Rejo Yogyakarta Tahun 2015.Skripsi Sekolah Tinggi Ilmu Kesehatan 'Aisyiyah, Yogyakarta.

Salman Y dkk. 2015. Hubungan Pola Konsumsi Zat Besi dan Kepatuhan Mengkonsumsi Tabelt Fe dengan Kejadian Anemia pada Ibu Hamil di Wilayah Kerja Puskesmas Sambung Makmur Tahun 2015.Jurkessia, Vol. VI, No. 2, Maret 2016 (hlm. 51-58).

Sarwono P 2014. Ilmu Kebidanan. Jakarta: Bina Pustaka.
Sulistiyanti A 2015. Hubungan Tingkat Pengetahuan Ibu Hamil tentang Anemia dengan Kepatuhan Konsumsi Tabelt Fe di Wilayah Kerja Puskesmas Masaran 1 Sragen.Jurnal Kebidanan dan Ilmu Kesehatan Volume 2/ Nomor 2/November 2015 (hlm.7-22).

Susiloningtyas I 2012. Pemberian Zat Besi (Fe) dalam Kehamilan.Skripsi Fakultas Ilmu Kesehatan Universitas Islam Sultan Agung, Semarang.

Syamsiah N 2011. Faktor-Faktor Yang Berhubungan dengan Kepatuhan Pasien CKD Yang Menjalani Hemodialisa di RSPAU Dr Esnawan Antariksa Halim Perdana Kusuma Jakarta. Tesis,Fakultas Ilmu Kesehatan Universitas Indonesia, Depok. 